\title{
Strategic Suppliers' Technical Contributions to New Product Advantage: Substitution and Configuration Options*
}

\author{
Benn Lawson, Beverly B. Tyler, and Antony Potter
}

Current theory lacks clarity on how different kinds of resources contribute to new product advantage, or how firms can combine different resources to achieve a new product advantage. While several studies have identified different firm-specific resources that influence new product advantage, comparatively little research has explored the contribution of strategic supplier resources. Combining resource-based and relational perspectives, this study develops a theoretical model investigating how a strategic supplier's technical capabilities impact focal firm new product advantage and how firms combine different resources to gain this advantage. The model is tested using detailed survey data collected from 153 interorganizational new product development projects in the United Kingdom within which a strategic supplier had been extensively involved. Empirical results support our research hypotheses. First, supplier technical performance is shown to have a significant positive impact on new product advantage. Next, we show that while supplier technical capabilities have a positive influence on supplier technical performance, the a priori nature of the supplier's task moderates the relationship. Finally, our data support our hypotheses related to the positive relationship between relationship-specific absorptive capacity and new product advantage, and the proposed negative moderation of supplier technical capabilities on this relationship. Based upon these findings, we encourage managers to recognize that strategic suppliers' with greater technical capabilities perform better regardless of the degree of creativity required by their task; but that strategic suppliers with lower technical capabilities may partially compensate (substitute) for their lack of technical capabilities, if they are able to respond to high problem-solving task requirements. Furthermore, we suggest that the firm's development of relationship-specific absorptive capacity is much more important when a strategic supplier is less technically capable. A buying firm's relationship-specific absorptive capacity can, according to our data, substitute for low supplier technical capabilities. On the other hand, where the supplier has strong technical capabilities, investments in relationship-specific absorptive capacity have no effect on new product advantage. Our findings reinforce recent calls for research on how firms can combine different resources and capabilities to achieve superior performance.

\section{Introduction}

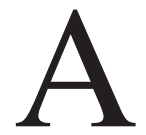

$\mathrm{s}$ firms increasingly invest in new product development (NPD), greater attention is being given to building a new product's advantage in the market. Managers often find that while their new products meet internal project goals, technical objectives, budget costs, and development schedules, they may fail when launched in the market because they do not offer superior product performance, relative to competitor offerings. Consequently, the ability of managers to ensure that their new products incorporate the latest technologies that surpass competitors' products is critical to success (McNally, Cavusgil, and Calantone, 2010). Capturing a new product advantage is thus an important strategic

Address correspondence to: Benn Lawson, Judge Business School, University of Cambridge, Cambridge CB2 1AG, UK. E-mail: b.lawson@ jbs.cam.ac.uk. Tel: +44-1223-760-567.

* This research was funded by a grant from the Engineering and Physical Sciences Research Council, UK (Grant Number: EP/E003990/1). objective for many firms within highly competitive industries (Atuahene-Gima and Wei, 2011; Droge, Calantone, and Harmancioglu, 2008; Rijsdijk, Langerak, and Hultink, 2011). It is a critical determinant of the success of a NPD project, and has been defined as the ability of the new product to offer unique features, meet customer needs, offer higher quality, and provide superior technical performance in comparison to its competitors' products (Song and Parry, 1997).

The product innovation literature has identified key firm-specific capabilities, such as market orientation, development speed, market learning, and product innovativeness that play an important role in determining new product advantage (Atuahene-Gima and Wei, 2011; Kim and Atuahene-Gima, 2010; Langerak and Hultink, 2005). Comparatively few studies, however, have examined the role of interorganizational NPD and the contribution of strategic suppliers to new product advantage (Lau, Yam, and Tang, 2011; Wynstra, von Corswant, and Wetzels, 2010). More specifically, research, to our knowledge, has 
not considered how firms configure their resources and those of their strategic suppliers to gain a new product advantage, or how different resource configurations allow firms to substitute one resource for another (Gruber, Heinemann, Brettel, and Hungeling, 2010; Hess and Rothaermel, 2011; Sirmon, Hitt, and Ireland, 2007; Tzabbar, Aharonson, and Amburgey, 2013). Given the increasing prevalence of interorganizational NPD projects, this represents a key gap in the literature.

Building on the product innovation, strategic management, and supply chain literature, we propose that firms that integrate strategic suppliers into their NPD projects are likely to gain a new product advantage by accessing and leveraging their suppliers' technical capabilities, as well as innovations that have yet to be integrated into competitor products (Petersen, Handfield, and Ragatz, 2005; Song, Song, and Di Benedetto, 2011; Wagner, 2012). Furthermore, we posit that firms can use different configurations of supplier-specific and firm-specific resources to obtain new product advantage (Gruber et al., 2010; Hess and Rothaermel, 2011; Sirmon et al., 2007). More specifically, we seek to answer three research questions: In technology-intensive dynamic industries, how do strategic suppliers' technical capabilities contribute to supplier

\section{BIOGRAPHICAL SKETCHES}

Dr. Benn Lawson is a senior lecturer in operations management at Cambridge Judge Business School, University of Cambridge, UK. He received his Ph.D. from the University of Melbourne. His research interests are in global production networks, and the intersection of supply chain management and new product development. His work has been published in outlets such as Journal of Product Innovation Management, Journal of Operations Management, Human Resource Management, and Journal of Supply Chain Management.

Dr. Beverly B. Tyler is a professor of management in the Poole College of Management, North Carolina State University. She applies behavioral theory using cognitive, organizational, and relationship management lenses to study executive and organizational decision-making, and intraorganizational and inter-organization cooperation in domains such as new product development, supply chain management, international investment decisions, and sponsored research relationships. Her research has appeared in Journal of Product Innovation Management, Strategic Management Journal, Journal of Management Studies, Journal of Operations Management, Journal of Supply Chain Management, and Journal of Engineering and Technology Management.

Dr. Antony Potter is a lecturer in operations management at Manchester Business School, University of Manchester. He received a Ph.D. from the University of Sheffield. His research interests focus on supplier involvement in new product development, supply chain risk, lean production systems, and the evolution of clusters and networks. He has published in Journal of Product Innovation Management, International Journal of Operations and Production Management, Trends in Food Science and Technology, Journal of Economic Geography, and Regional Studies. technical performance and new product advantage? Is this contribution moderated by the problem-solving requirements of the supplier's product development task? Do strategic supplier technical capabilities moderate the relationship between the firm's relationship-specific absorptive capacity and new product advantage?

Resource-based and relational perspectives are adopted to propose different configurations of strategic supplier and firm resources, which can be used to gain new product advantage and sustain their product's competitive position within the market (Barney, 1991; Dierickx and Cool, 1989; Reed and DeFillippi, 1990). We empirically assess our hypotheses using detailed survey data collected from 153 interorganizational NPD projects in the United Kingdom within which a strategic supplier had been extensively involved. The data provide support for each of our hypotheses, suggesting that different configurations of firm-specific and strategic supplier-specific resources contribute to new product advantage.

This study makes two important contributions to the product innovation management literature. First, we extend the literature by examining how strategic suppliers' technical capabilities affect the development of new product advantage in interorganizational NPD projects. In particular, we find that not only do supplier technical capabilities positively affect supplier technical performance, which in turn positively affects new product advantage, but these resources can also substitute for buyer relationship-specific absorptive capacity. Our results provide a nuance to the literature on absorptive capacity highlighting its importance where supplier technical capabilities are low and the firm must invest in relationship-specific absorptive capacity in order to extract useful technology and innovation. Second, we reveal how the problem-solving requirements of the supplier's task moderates the effect of supplier technical capabilities on supplier technical performance. Although problem-solving task requirement has minimal moderating effect on the relationship between strategic suppliers with high technical capabilities and supplier technical performance, the impact of low supplier technical capabilities on supplier technical performance varies significantly under high and low problem-solving task conditions. It would appear in our sample that some suppliers with lower technical capabilities have developed problem-solving capabilities that allow them to compensate somewhat for their constrained technical capabilities in order to increase their overall technical performance. We thus also contribute to the literature on resource constraints in product development settings (Gibbert, Hoegl, and Valikangas, 2013). 
In the pages below, we begin by providing a brief overview of the relevant literatures and, then, develop our specific hypotheses. Next, we report our methodology and empirical findings. We conclude with a discussion of the study's implications, limitations, and future directions.

\section{Theory and Hypothesis Development}

\section{New Product Advantage}

Early studies by Cooper and Bruno (1977) identified a significant positive relationship between the level of new product success and measures of product competitive advantage, such as the presence of unique features, relatively high product quality, and the ability to reduce consumer costs. More recently, studies have continued to find significant relationships between new product advantage and several measures of product success, including objective measures of financial performance (Hua and Wemmerlöv, 2006; McNally et al., 2010; Song and Parry, 1996, 1997; Song, Souder, and Dyer, 1997). Thus, new product advantage is defined as "a product's perceived superiority to competitive products" (Song and MontoyaWeiss, 2001) and is concerned with the product's technical performance and quality, and the degree to which it meets customers' needs with unique features and capabilities (Song et al., 1997). While the product innovation literature has studied new product advantage extensively, it has seldom been considered in relation to strategic supplier involvement in NPD projects.

\section{Resource-Based and Relational Views of Resource Development}

According to the resource-based view of the firm, advantage accrues from heterogeneous and immobile resources that have accumulated over time (Collis, 1994; Dierickx and Cool, 1989; Wernerfelt, 1984). More specifically, Barney (1991, p. 116) argues that the "source of sustained competitive advantage are firm resources that are valuable, rare, imperfectly imitable, and non-substitutable." Resources with these characteristics cannot easily be imitated due to causal ambiguity and resource scarcity (Kogut and Kulatilaka, 2001). This perspective defines resources as physical and intangible resources and the organizational capabilities to manage those resources, and posits that capabilities are typically harder to imitate than other resources because of their complexity and ambiguity (Barney, 1991). The path-dependent nature of firm resources are recognized, but it is acknowledged that firms with greater resources will enjoy greater "appropriability advantages" and enhanced flexibility with which to respond in turbulent, dynamic environments (Kraatz and Zajac, 2001; Nelson and Winter, 1982).

The resource-based view, and the competence perspective more broadly defined, recognize not only the potential for firm-specific resources to provide a competitive advantage, but also acknowledge that firms access and leverage alliance partners' resources to maintain and continuously renew, augment, and adapt their resources to gain and retain a competitive advantage (Helfat and Peteraf, 2003; Mesquita, Anand, and Brush, 2008). Moreover, this perspective recognizes that in dynamic environments, firms use dynamic capabilitiesorganizational processes by which members manipulate resources to develop new value-creating strategies (Eisenhardt and Martin, 2000; Teece, Pisano, and Shuen, 1997) — to blend modular existing and new resources into new resource combinations or apply simple rules to improvise with loosely coupled resources to shift from leveraging existing resources to seize opportunities using novel combinations of new and existing resources (Davis and Eisenhardt, 2011; Davis, Eisenhardt, and Bingham, 2009; Santos and Eisenhardt, 2005). Thus, the resourcebased or competence perspective posits that at any given point in time, a firm's capability portfolio and that of their strategic suppliers reflect their coevolution of resources with environmental opportunities (Laamanen and Wallin, 2009; Volberda and Lewin, 2003).

The relational view of the firm emphasizes how firms sense, seize, and transform resources sourced from strategic suppliers to earn relational rents and develop competitive advantage using mechanisms such as supplier selection and development processes, investments in relationship-specific assets, appropriate governance mechanisms, and interfirm routines for communication, information sharing, mutual planning, and problem solving (e.g., Dyer, Kale, and Singh, 2001; Dyer and Singh, 1998). We define strategic suppliers as important suppliers that firms have made a long-term commitment to, due to their strategic inputs-inputs that are typically high value added and play a role in differentiating the firm's final product, and have developed a relationship with in order to leverage strategic and operational capabilities of the individual companies to achieve ongoing benefits to each party (Dyer, Cho, and Chu, 1998; Monczka, Petersen, Handfield, and Ragatz, 1998). These relationships are characterized by a high degree of coordination at multiple functional-to-function interfaces, relation-specific asset investments, and interfirm 
knowledge-sharing routines (Dyer and Hatch, 2006; Dyer and Nobeoka, 2000; Dyer et al., 1998). Furthermore, strategic suppliers are typically involved early and extensively in new product development, allowing the firm to access suppliers' skills, creativity, and technology (Clark, 1989; Handfield, Ragatz, Petersen, and Monczka, 1999; Lau, Tang, and Yam, 2010; Petersen, Handfield, and Ragatz, 2003). While the relational view has long recognized that complementary resources are a major driver for relational rents and competitive advantage in individual alliances (Dyer and Singh, 1998), research has only begun to consider how new product development process characteristics can moderate the relationship between resources and product innovation (Fang, 2011) and how firm and supplier resource combinations can substitute for one another in NPD (Hess and Rothaermel, 2011; Weigelt, 2013).

\section{Theoretical Framework and Hypotheses Development}

Combining the resource-based and relational perspectives, we explore how strategic suppliers' technical capabilities help firms generate new product advantage (Azadegan and Dooley, 2010; Wagner, 2012). More specifically, we investigate how the supplier's technical capabilities influence their technical performance, which in turn affects the firm's new product advantage (see Figure 1). We also consider how the relationship between a supplier's technical capabilities and their technical performance is moderated by the creative problem-solving requirements of their task (Atuahene-Gima and Wei, 2011). Finally, we assess the relationship between firm's relationship-specific absorptive capacity and their new product advantage, and the moderating effect of the strategic supplier's technical capabilities on this relationship (Ettlie and Pavlou, 2006).

\section{Supplier Technical Performance, Supplier Technical Capabilities, and New Product Advantage}

The involvement of strategic suppliers in new product development processes is of increasing strategic importance, with firms relying on these suppliers to deliver or further develop technologies for their NPD efforts (Ragatz, Handfield, and Scannell, 1997; Song et al., 2011). Such suppliers are able to perform multiple tasks that assist firms struggling to understand or develop new technology that surpasses their competitors' technologies (Clark, 1989; Handfield et al., 1999; Lau et al., 2010; Petersen et al., 2003). Strategic suppliers' strong technical performance contributes advanced technical knowledge, new technology advancements, and creative problem solving (e.g., Rauniar, Doll, Rawskic, and Hong, 2008; Wasti and Liker, 1997; Womack, Jones, and Roos, 1990), which assists firms in establishing new product advantage. Finally, strategic suppliers can also provide buyers with market intelligence on the capabilities of their competitors, helping them benchmark performance and ensure that their technical capabilities are superior (Handfield, 2006). These arguments lead us to hypothesize that increases in strategic supplier technical performance will result in improved new product advantage.

H1: The greater the strategic supplier's technical performance, the greater the firm's new product advantage relative to competitors' products.

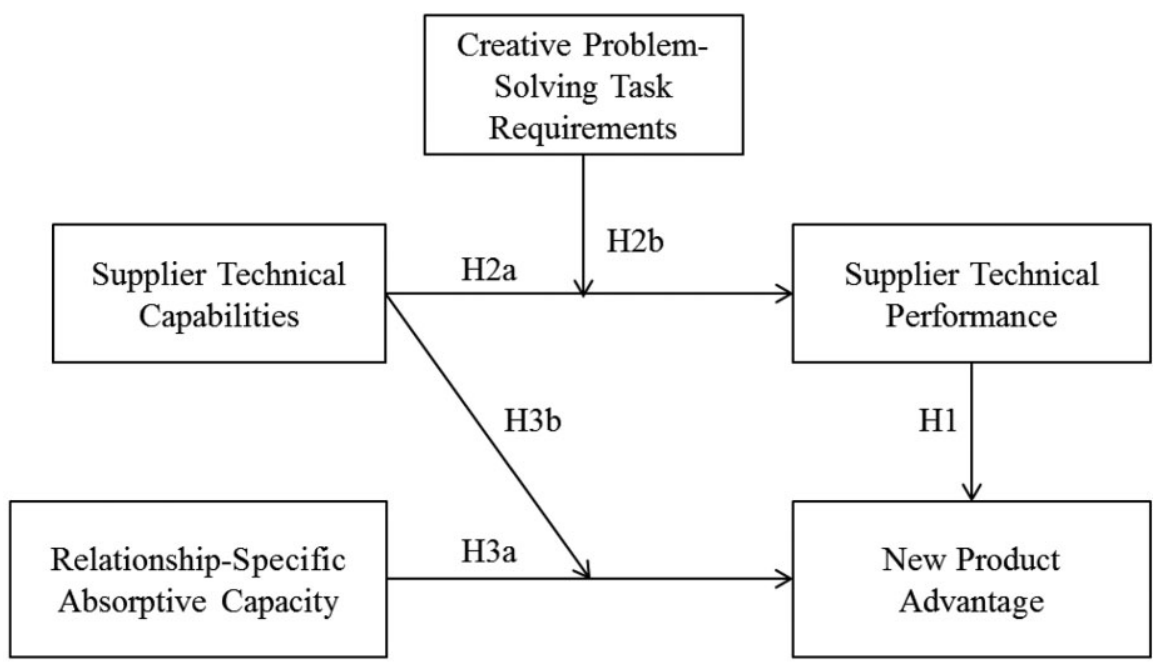

Figure 1. Theoretical Framework 
Consistent with the resource-based view, firms are expected to recognize a strategic supplier's unique technical capabilities, which can be leveraged in NPD-related activities (Emden, Calantone, and Droge, 2006). A supplier's technical competence helps to practically develop the product by testing and evaluating its technical specifications (Pavlou and El Sawy, 2006). van Echtelt, Wynstra, and van Weele (2007, p. 182) emphasize the importance of supplier technical capabilities in their definition of supplier involvement as "the resources (capabilities, investments, information, knowledge, ideas) that suppliers provide, the tasks they carry out and the responsibilities they assume regarding the development of a part, process, or service for the benefit of a buyer's current or future product development project." Thus, a supplier's technical capabilities can be defined as the extent to which "a supplier has the resources to create and respond to emerging technologies" (LaBahn and Krapfel, 2000, p. 177). Womack et al. (1990) observed that a supplier's stock of technical know-how is one of their primary means of competing, and Håkansson (1982) argued that sophisticated component suppliers compete by leveraging their technical knowledge in order to pursue relationships in which they can profitably apply and refine their expertise. Furthermore, firms who involve strategic suppliers early in NPD design work are better able to capitalize on their in-house technical capabilities and capabilities (Wasti and Liker, 1997) and reduce development delays (Hartley, Zirger, and Kamath, 1997). Finally, strategic suppliers with developed technical capabilities help to reduce the prevalence of costly design glitches and technical errors for the focal firm (Rauniar et al., 2008). Based on these findings, we propose that as a strategic supplier's technical capabilities increase, their technical performance will increase.

H2a: The greater the strategic supplier's technical capa-

bilities, the greater the supplier's technical performance.

Both the resource-based and relational perspectives recognize the importance of firms and their suppliers developing independent as well as joint problem-solving capabilities. Research by Clark (1989) and Clark and Fujimoto (1991) identified a key benefit of strategic supplier involvement as its ability to create overlapping and integrated problem-solving cycles that span the buyersupplier interface. Takeishi (2001) found that a higher level of focal firm internal coordination affected component development indirectly through problem-solving patterns established with external suppliers. Furthermore, Bstieler and Hemmert (2010) showed that shared problem solving plays a crucial role in helping to solve technical problems and design defects that frequently occur during the early stages of new product development. Moreover, Atuahene-Gima and Wei (2011) suggested that problem-solving speed and problem-solving creativity are key determinants of product quality and new product advantage. Finally, Fang (2011) found that NPD process characteristics associated with joint problem solving moderate the relationship between alliance partner knowledge complementarity and product innovation.

This literature suggests that the more creative problem solving required by strategic suppliers to perform their requisite tasks, the less impact their technical capabilities will have on their technical performance as assessed by the buying firm. We suggest two reasons creative problem solving task requirements will attenuate (negatively moderate) the impact of technical capabilities on strategic suppliers' performance. First, as problem-solving requirements increase, suppliers' technical capabilities become less directly related to their technical performance, due to increased process interdependence, complexity, and causal ambiguity (Barney, 1991; Fang, 2011; Kogut and Kulatilaka, 2001). As supplier tasks become more interdependent, complex, and ambiguous, buyers assessing supplier performance will be less able to specify how suppliers' technical capabilities directly impacted their technical performance. Second, buying firms may consider the problem-solving requirements of the supplier's task simply part of the job, a responsibility of the strategic supplier, and, thus, only assess the final performance-unconcerned with how the strategic supplier performed the task. After all, research on buyersupplier exchanges found that while suppliers considered joint sensemaking a significant predictor of relationship performance, buyers did not (Cheung, Myers, and Mentzer, 2011). Thus, it is anticipated that the level of creative problem solving required to accomplish the NPD tasks assigned to strategic suppliers will moderate the impact of their technical capabilities on their technical performance.

H2b: The level of creative problem solving required by the supplier's NPD task moderates the relationship between the supplier's technical capabilities and their technical performance.

\section{Relationship-Specific Absorptive Capacity and New Product Advantage}

The resource-based and relational perspectives agree that firms are motivated to develop their ability to absorb and integrate technical knowledge from their strategic 
suppliers in order to sense, seize, and transform new technical knowledge required to gain and retain new product advantage (Gulati, 1995). This is most likely when strategic suppliers have distinct yet complementary technical capabilities, when partners through collaboration may gain access to new technology or innovations, or the firm may gain access to a new market while the supplier has the opportunity to become a value-added supplier (Dyer and Singh, 1998; Emden et al., 2006). Evidence also suggests that the presence of overlapping knowledge is a necessary condition for firms to absorb the technical knowledge developed by their strategic suppliers (Tanriverdi and Venkatraman, 2005) because if there is insufficient knowledge overlap, firms will be unable to realize the technology's potential, discover the complementarities of their resources, and communicate these complementary resources interorganizationally (Emden et al., 2006). For example, Takeishi (2001) found that an NPD project in which an automaker's engineers had a higher level of knowledge about an outsourced component exhibited a higher level of component design quality. In a similar vein, Brusoni, Prencipe, and Pavitt (2001) showed that focal firms need to have knowledge, in excess of what they need for what they make, to cope with and adapt to imbalances caused by uneven rates of development in the technologies they rely on. Furthermore, research evaluating cooperative strategies has emphasized the importance of developing partnerspecific knowledge-sharing routines with strategic suppliers in order to absorb technical knowledge to gain a competitive advantage (Dyer, 1996; Dyer and Singh, 1998). Finally, the resource-based perspectives suggest that firms may need to integrate strategic suppliers' technology with their own internal technical capabilities after they absorb it, if they hope to create new product advantage (Abecassis-Moedas and Mahmoud-Jouini, 2008). Thus, both the resource-based and relational research suggests the following hypothesis:

\section{H3a: The greater the firm's relationship-specific absorp- tive capacity, the greater the new product advantage achieved relative to competitors' products.}

However, the impact of the focal firm's relationshipspecific absorptive capacity on new product advantage can be expected to vary based on the level of the strategic supplier's technical capabilities for at least two reasons. First, strategic alliance research looking at different resource combination effects on innovative performance has found that resource combinations that focus on the same upstream value chain activities provide redundant knowledge and are substitutes (Hess and Rothaermel,
2011). Resources are substitutes for one another if doing more of an activity to leverage a resource reduces the marginal benefit of another (Arora and Ceccagnoli, 2006; Cassiman and Veugelers, 2006). Firms may determine that the degree of interaction required to absorb strategic suppliers' strong technical capabilities increases coordination costs and increases the chance of unintended technology leakage (Contractor, Woodley, and Piepenbrink, 2011), and, thus, forgo these costs by outsourcing technical capabilities from strong strategic partners. For example, strategic suppliers with strong technical capabilities will often be developing new "sticky" knowledge that firms will find difficult to access and costly to transfer across interorganizational boundaries, even when they seek to develop relationship-specific absorptive capabilities (von Hippel, 1994). Furthermore, when a strategic supplier's technical capabilities are considered their core competencies, it will become increasingly difficult and costly for firms to absorb a strategic supplier's technical knowledge because of the supplier's fear of opportunism and loss of bargaining power (Simonin, 1999).

Second, research that compares resource-based and relational perspectives to examine competitive advantages in vertical relationships has found that the resourcebased view helps to explain performance gains if the new capabilities lie entirely within the supplier's boundaries, while the relational view reveals the gains that are exclusive to the learning partnership (Mesquita et al., 2008). Consistent with a resource-based perspective, strategic suppliers that have developed strong technical capabilities through specialization can further enhance their resources by applying and deploying them across a number of buyers (Mesquita et al., 2008). Although this will not constitute a unique application to the buyer, the strategic suppliers' technical capabilities will still be valuable because they reflect industry best practices (Weigelt, 2013). Outsourcing strong technical capabilities from a strategic supplier may be particularly beneficial for a technically weak buyer, as industry best practices have a greater relative advantage for weaker buyers than for stronger buyers (Jacobides and Winter, 2005).

On the other hand, the relational view recognizes the performance gains exclusive to the learning relationship as a function of the focal firms acquiring know-how within the dyad and developing relationship-specific capabilities with a strategic supplier (Mesquita et al., 2008). A higher degree of interaction and the associated increase in coordination costs may be worthwhile, if the strategic supplier has a lower level of technical expertise (Contractor et al., 2011). Under these condi- 
tions the technically weaker strategic supplier will be less fearful of opportunism and loss of bargaining power (Simonin, 1999), or the chance of unintended technology leakage (von Hippel, 1994). Furthermore, the firm will need overlapping knowledge to absorb the technical knowledge developed by their strategic suppliers in order to realize the technology's potential, discover the complementarities of their resources, and communicate these complementary resources interorganizationally (Emden et al., 2006; Tanriverdi and Venkatraman, 2005). Finally, the firm will need to be more capable of evaluating the quality of the supplier's technical capabilities, and absorbing and integrating these resources, because they will be less willing to be dependent on a technically weak strategic supplier to perform the task alone. These pressures are likely to require the firm to invest in additional absorptive capacity to extract strategic supplier's technical capabilities in aid of building a new product advantage.

H3b: The strategic supplier's technical capabilities moderate the relationship between the firm's relationshipspecific absorptive capacity and the new product advantage achieved relative to competitors' products.

\section{Method}

\section{Sample Characteristics}

The present study is part of a broader research effort to investigate supplier involvement in NPD. Other papers drawing on this data set include Lawson and Potter (2012), Potter and Lawson (2013), and Lawson, Krause, and Potter (In Press). A sample of 1700 R\&D intensive medium-to-large manufacturing firms was obtained from the UK Department of Trade and Industry (DTI). Firms were selected according to their SIC industrial classification and plant size (at least 100 employees). In addition, telephone calls were made to each of the firms to confirm our screening criteria were met and to identify a respondent within the firm familiar with a strategic supplier's role in a new product development project. These data screening procedures indicated that 204 firms did not meet our selection criteria, resulting in a final sample of 1496 firms. We received 160 questionnaires from respondents, of which seven contained missing data and were discarded. The final sample is 153 firms, giving a $10.3 \%$ response rate. Table 1 provides further details of the sample characteristics.

Of the responding firms, industries represented were automotive $(8.5 \%)$, aerospace $(14.4 \%)$, pharmaceutical
Table 1. Sample Characteristics

\begin{tabular}{|c|c|c|}
\hline (1) Industry & Frequency & $\%$ \\
\hline Aerospace & 22 & 14.4 \\
\hline Automotive & 13 & 8.5 \\
\hline Chemicals and chemical products & 18 & 11.8 \\
\hline Electronic and industrial equipment & 54 & 35.3 \\
\hline General manufacturing & 17 & 11.1 \\
\hline Pharmaceutical & 16 & 10.4 \\
\hline Not reported & 13 & 8.5 \\
\hline Total & 153 & 100.0 \\
\hline (2) Business Units' Annual Sales & Frequency & $\%$ \\
\hline Under $£ 25 \mathrm{M}$ & 52 & 34.0 \\
\hline$£ 25-£ 50 \mathrm{M}$ & 18 & 11.8 \\
\hline$£ 50-£ 100 \mathrm{M}$ & 15 & 9.8 \\
\hline$£ 100-£ 250 \mathrm{M}$ & 17 & 11.1 \\
\hline$£ 250-£ 500 \mathrm{M}$ & 15 & 9.8 \\
\hline Over $£ 500 \mathrm{M}$ & 20 & 13.1 \\
\hline Missing & 16 & 10.5 \\
\hline Total & 153 & 100.0 \\
\hline (3) Titles & Frequency & $\%$ \\
\hline Operations manager & 30 & 19.6 \\
\hline $\mathrm{R} \& \mathrm{D}$ manager & 26 & 17.0 \\
\hline Purchasing manager & 59 & 38.5 \\
\hline Procurement director & 24 & 15.7 \\
\hline Missing & 14 & 9.1 \\
\hline Total & 153 & 100.0 \\
\hline (4) Location of Suppliers & Frequency & $\%$ \\
\hline UK & 75 & 49.0 \\
\hline USA & 14 & 9.1 \\
\hline Germany & 8 & 5.2 \\
\hline France & 5 & 3.3 \\
\hline Europe other & 21 & 13.7 \\
\hline China & 15 & 9.8 \\
\hline Asia-Pacific & 10 & 6.6 \\
\hline Missing & 5 & 3.3 \\
\hline Total & 153 & 100.0 \\
\hline
\end{tabular}

(10.4\%), electrical $(35.3 \%)$, chemicals $(11.8 \%)$, and general manufacturing $(11.1 \%)$. The final $11 \%$ of firms had no response to industry classification. The response by position held within the firm was operations manager $(19.6 \%)$, research and development manager $(17.0 \%)$, purchasing manager $(38.5 \%)$, and procurement director $(15.6 \%)$. No significant mean differences were detected between these groups, or across functional departments. The average number of years respondents had worked with the firm was 9.2 years, with 3.2 years in their current job position, providing support that our informants were also knowledgeable about their firm's capabilities.

\section{Survey Administration}

The unit of analysis was an interorganizational NPD project. Respondents were instructed to select a supplier 
that had been extensively involved in an interorganizational NPD project within the last 3 years and had provided a critical component or subassembly to the buyer firm's end product. Given our use of a single key informant, we undertook an additional validation check, asking respondents their level of knowledge of the supplier relationship and NPD project, using a Likert scale of 1-7, where 7 represented "extensive knowledge" (Kumar, Stern, and Anderson, 1993). A mean response of 5.8 (out of 7) provides confidence that respondents were knowledgeable regarding the items under investigation.

Semi-structured interviews to develop and refine the questionnaire were conducted initially with 10 managers across the purchasing, project management and product design functions. The instrument was then pilot tested with a further 10 managers and 6 academic experts who provided further feedback on the design, content, clarify, and scaling. Each respondent was sent a copy of the questionnaire by mail, together with a cover letter outlining the purpose of the research project. To elicit responses, a number of procedures outlined by Dillman, (2000) were adopted, including allowing responses by return mail or Internet, offering a composite summary of results and sending a reminder postcard 2 weeks after the initial mailing. After 6 weeks, a follow-up call to nonresponders was also made. Tests were also undertaken to detect response biases, such as between early and late responders (Armstrong and Overton, 1977). No significant differences were identified. Further representative checks were also made using Pearson's chi-square tests to identify if there was any over- or underrepresentation of particular types of firms in our sample (Greene, 2002). Although our analysis does not rule out the potential for response bias, the findings identify that the sample is broadly representative.

\section{Operationalization of Variables}

All constructs were previously validated and drawn from the extant literature. Items were assessed on a Likert scale ranging from 1 "strongly disagree" to 7 "strongly agree." Table 2 provides further details of these measures.

New product advantage. A scale originally validated by Song and Parry (1997) is adopted, with respondents asked to assess their firm's new product compared with those of competitors' products in terms of unique features, technical performance, quality, enabling customers' to do something they could not presently do, and meeting customers' needs.
Supplier technical performance. Following Carson (2007), we examine a strategic supplier's content contributions to ex post performance, namely their contribution to technology. The contribution of supplier's technology construct asked respondents to characterize the supplier's technology contribution to the NPD project in terms of its anticipated effect on competitiveness, functionality, and profitability of the new product.

Supplier technical capabilities. A scale originally developed by LaBahn and Krapfel (2000) was used to assess the extent to which the supplier could incorporate the latest technology in their products, was proficient with the latest technology, was skilled at creating technological innovations, was able to respond quickly to technological changes, and could offer a high degree of engineering support.

Creative problem-solving task requirements. A scale originally developed by Andrews and Smith (1996) and adapted by Carson (2007) was used to measure the a priori level of creative problem solving required by the supplier in order to perform their work successfully. Since the extent of problem solving required is idiosyncratic to the supplier, the items capture the strategic supplier's characteristics in terms of their a priori required process innovativeness, creativity, and imagination for the project.

Relationship-specific absorptive capacity. Ettlie and Pavlou's (2006) measure was used to capture the degree of relative absorptive capacity. This measure focuses on the integration of firm-specific and supplier-specific knowledge pools, the exploitation of the supplier's knowledge, the routines used to obtain the supplier's technological knowledge, and the firm's ability to identify, value, and import knowledge from the particular supplier.

Control variables. A series of control variables were also used within the multivariate ordinary least squares (OLS) regression models. Industry effects were controlled for using three dummy variables for the automotive industry, aerospace industry, and electronics industry. The hold-out sample was categorized as other. We control for firm size (log of employees). To reflect the nature of the supplier relationship, we controlled for relationship length (log of months) (Wasti and Liker, 1997), long-term relationship commitment (Paulraj, Lado, and Chen, 2008), evaluation effort in the supplier selection process 
Table 2. Confirmatory Factor Analysis

\begin{tabular}{|c|c|c|c|}
\hline Factors and Items & $\begin{array}{l}\text { Standardized } \\
\text { Loading }\end{array}$ & $\begin{array}{l}\text { Error } \\
\text { Term }\end{array}$ & $t$-value \\
\hline \multicolumn{4}{|l|}{ New product advantage: Relative to competitors' products, our new product... } \\
\hline Offered unique features or attributes to the customer & .92 & - & - \\
\hline Was clearly superior in terms of meeting customers' needs & .91 & .06 & 17.17 \\
\hline Had superior technical performance & .61 & .09 & 8.58 \\
\hline Offered higher quality—tighter specs, stronger, lasted longer, or more reliable & .65 & .07 & 9.36 \\
\hline Permitted the customer to do a job or do something he could not presently do & .84 & .06 & 14.72 \\
\hline \multicolumn{4}{|l|}{ Supplier Technical Performance: The supplier's technology will contribute a great deal ... } \\
\hline to the competitiveness of our products & .80 & - & - \\
\hline to the functionality of our products & .77 & .10 & 9.03 \\
\hline to the profitability of our products & .71 & .10 & 8.37 \\
\hline \multicolumn{4}{|l|}{ Supplier Technical Capabilities: This supplier. . . } \\
\hline could incorporate the latest technology in their products & .81 & - & - \\
\hline was proficient with the latest technology & .94 & .07 & 14.54 \\
\hline was skilled at creating technological innovations & .95 & .08 & 14.61 \\
\hline was able to respond quickly to technological changes & .72 & .09 & 9.81 \\
\hline could offer a high degree of engineering support to us & .74 & .08 & 10.20 \\
\hline \multicolumn{4}{|l|}{ Relationship-Specific Absorptive Capacity: Relative to competitors, how well can your firm... } \\
\hline integrate our existing knowledge with new knowledge acquired from this supplier & 61 & .13 & 6.29 \\
\hline exploit the new integrated knowledge into concrete applications & 62 & - & - \\
\hline internal routines to analyze the knowledge obtained from this supplier & .89 & .16 & 7.80 \\
\hline identify, value, and import external knowledge from this supplier & .76 & .17 & 7.43 \\
\hline \multicolumn{4}{|l|}{ Creative Problem-Solving Task Requirement: The nature of the supplier's work... } \\
\hline The supplier's work demanded a lot of creativity and imagination & .77 & - & - \\
\hline To perform its work well, the supplier had to be inventive and discover how to do new things & .64 & .13 & $6.85-$ \\
\hline The technology produced by the supplier had to incorporate significant new knowledge & .78 & .12 & 7.63 \\
\hline The technology was only a slight departure from technology that the supplier had produced & & & \\
\hline \multicolumn{4}{|l|}{ Long-Term Relationship Commitment: The nature of the supplier relationship ... } \\
\hline Our relationship with this supplier is of very little significance to us (r) & .77 & - & - \\
\hline Our relationship with this supplier is long-term in nature & .91 & .09 & 12.56 \\
\hline We are committed to the preservation of this relationship & .94 & .10 & 13.01 \\
\hline The supplier sees our relationship as a long-term alliance & .87 & .11 & 11.81 \\
\hline We expect to be working with this supplier for the foreseeable future & .51 & .11 & 6.42 \\
\hline \multicolumn{4}{|l|}{ Evaluation Effort: The level of ex ante effort in evaluating the supplier's... } \\
\hline product quality & .81 & - & - \\
\hline manufacturing capability & .66 & .08 & 8.36 \\
\hline delivery capability & .81 & .07 & 10.55 \\
\hline technical capability & .71 & .09 & 9.07 \\
\hline financial viability & .76 & .08 & 9.87 \\
\hline
\end{tabular}

${ }^{\text {a }}$ Deleted due to low loading; (r), reverse coded.

(Song and Di Benedetto, 2008), and supplier criticality (measured by a single sourcing strategy) (Richardson and Roumasset, 1995). The contribution of the supplier to the project was also accounted for by item importance, coded as 1 or 0 , capturing whether the supplier provided a subassembly to the firm (Liker, Kamath, Wasti, and Nagamachi, 1996), as well as supplier responsibility, reflecting the percent of total engineering hours for the new product attributable to the supplier (Clark and Fujimoto, 1991; Liker et al., 1996). The advantage gained by the new product in the market may be influenced by its degree of underlying technological innovation; thus, we control for the degree of technological newness on a 1-4 scale (Takeishi, 2001).

\section{Data Analysis}

Confirmatory factor analysis (CFA) was used to test for construct validity and unidimensionality using latent and manifest variables. Within each construct, one of the loadings was fixed to the value of one. Low factor loadings, high residual values, and modification indices were examined. One item from supplier creative problemsolving task requirements was removed due to low 
Table 3. Correlation Matrix and Descriptive Statistics

\begin{tabular}{|c|c|c|c|c|c|c|c|c|c|c|c|c|c|c|c|c|}
\hline Variable $^{\mathrm{a}, \mathrm{b}}$ & 1. & 2. & 3. & 4. & 5. & 6. & 7. & 8. & 9. & 10. & 11. & 12. & 13. & 14. & 15 . & 16. \\
\hline 1. New product advantage & .90 & & & & & & & & & & & & & & & \\
\hline 2. Supplier technical performance & .22 & .81 & & & & & & & & & & & & & & \\
\hline 3. Relationship-specific absorptive capacity & .25 & .21 & .81 & & & & & & & & & & & & & \\
\hline 4. Supplier technical capabilities & .25 & .56 & .23 & .91 & & & & & & & & & & & & \\
\hline 5. Creative problem-solving task requirement & .02 & .39 & .16 & .40 & .76 & & & & & & & & & & & \\
\hline 6. Industry-automotive & -.08 & -.02 & .01 & .09 & .03 & - & & & & & & & & & & \\
\hline 7. Industry-aerospace & -.09 & .07 & -.10 & .09 & .11 & -.12 & - & & & & & & & & & \\
\hline 8. Industry-electronics & .17 & .09 & .05 & .05 & -.04 & -.23 & -.31 & - & & & & & & & & \\
\hline 9. Firm size (employees) & -.06 & .01 & -.04 & -.03 & .09 & .10 & .14 & -.10 & - & & & & & & & \\
\hline 10. Single supplier & .11 & -.04 & .08 & .05 & .00 & .16 & -.08 & -.08 & -.19 & - & & & & & & \\
\hline 11. Relationship length & .19 & .07 & .15 & .09 & .06 & .09 & -.01 & .05 & .13 & -.05 & - & & & & & \\
\hline 12. Evaluation effort & .27 & .22 & .15 & .22 & .10 & .10 & .09 & -.07 & .17 & -.13 & .14 & .86 & & & & \\
\hline 13. Long-term relationship commitment & .03 & .40 & .23 & .42 & .18 & .06 & .07 & -.04 & .05 & -.01 & .32 & .27 & .90 & & & \\
\hline 14. Technological newness & .33 & -.03 & .00 & .06 & .05 & .04 & .04 & -.05 & .10 & .09 & -.10 & .02 & -.12 & - & & \\
\hline 15. Supplier responsibility & -.13 & .06 & .06 & .08 & .24 & -.08 & .00 & -.07 & -.12 & .01 & -.15 & -.08 & -.13 & -.18 & - & \\
\hline 16. Item importance & .23 & .00 & -.07 & .10 & -.02 & -.12 & .06 & .07 & -.07 & .12 & -.07 & -.07 & -.09 & .15 & .03 & - \\
\hline Mean & 5.29 & 4.63 & 4.74 & 5.20 & 3.93 & .08 & .14 & .36 & 5.56 & .59 & 3.86 & 5.37 & 5.91 & 2.71 & .30 & .42 \\
\hline Standard deviation & 1.31 & 1.35 & .97 & 1.23 & 1.31 & .28 & .35 & .48 & 1.83 & .49 & 1.24 & 1.09 & 1.10 & 1.06 & .28 & .50 \\
\hline Composite reliability & .89 & .80 & .82 & .92 & .78 & & & & & & & .87 & .91 & & & \\
\hline Average variance extracted & .63 & .58 & .53 & .70 & .54 & & & & & & & .57 & .66 & & & \\
\hline
\end{tabular}

a Cronbach's alpha shown in bold on the diagonal.

${ }^{\mathrm{b}} n=153$; correlations $(p<.05)$ shown in italics.

loadings. Table 2 presents the details of the loadings and error terms of the manifest variables onto each latent variable. Model fit was examined using four measures: the chi-square test, the comparative fit index (CFI), the Tucker-Lewis index (TLI), and the root mean square error of approximation index (RMSEA) (Gerbing and Anderson, 1992). The fit of the CFA to the data was satisfactory $\left(\chi^{2}[383]=645.96 ; p=.00 ; C F I=.91\right.$; $\mathrm{TLI}=.90$; and RMSEA $=.067$ ).

A number of procedures were then followed to assess convergent validity (Bagozzi and Yi, 1988) and discriminant validity (Anderson and Gerbing, 1988; Fornell and Larcker, 1981). The convergent validity of the scales (extent to which the measurement items reflect a common underlying construct) was supported, with estimated coefficients of all indicators being significant $(t>2.0)$. The average variance extracted (AVE), which measures the variance captured by the indicators relative to measurement error, was also greater than the .50 minimum necessary to justify the use of a construct (Hair, Black, Babin, Anderson, and Tatham, 2006). Composite reliability (CR) values also provide a further assessment of internal consistency. A minimum value of .70 is recommended as it indicates that around .50 of the variance (the squared loading) can be attributed to the construct of interest (Fornell and Larcker, 1981). The CR, which ranged from .78 to .92 , each met the required level.
All tests of discriminant validity were supportive. That is, no confidence intervals of the correlations for the constructs $(\phi$ values) included $1.0(p<.05)$ (Anderson and Gerbing, 1988), and the square of the intercorrelations between two constructs, $\phi^{2}$, was less than the AVE estimates of the two constructs. This was true for all pairs of constructs (Fornell and Larcker, 1981). Interitem correlations, Cronbach's alpha, CR, and AVE values are shown in Table 3.

Multivariate OLS regression models were then used to test each of the hypothesized relationships within the theoretical model. Variance inflation factors (VIF) were also examined to test for multicollinearity. All VIFs ranged from 1.13 to 1.84 ; therefore, it is reasonable to conclude that the data set is clear of any multicollinearity issues (Hair et al., 2006).

\section{Results}

The results shown in Table 4 provide support for the hypothesized relationships within the theoretical model. A significant positive relationship for strategic supplier technical performance to new product advantage ( $\beta=.20$, $p<.05)$ provides support for H1. Consistent with expectations, $\mathrm{H} 2$ was supported with a significant positive association between supplier technical capabilities and strategic supplier technical performance $(\beta=.40$, 
Table 4. Standardized Coefficient Estimates of Regressions

\begin{tabular}{|c|c|c|c|c|}
\hline Variables & $\begin{array}{c}\text { Supplier } \\
\text { Technical } \\
\text { Performance } \\
\text { Model } 1\end{array}$ & $\begin{array}{c}\text { Supplier } \\
\text { Technical } \\
\text { Performance } \\
\text { Model } 2\end{array}$ & $\begin{array}{c}\text { New } \\
\text { Product } \\
\text { Advantage } \\
\text { Model } 3\end{array}$ & $\begin{array}{c}\text { New } \\
\text { Product } \\
\text { Advantage } \\
\text { Model } 4\end{array}$ \\
\hline \multicolumn{5}{|l|}{ Control variables: } \\
\hline Industry — automotive & -.05 & -.05 & -.12 & -.15 \\
\hline Industry-aerospace & .01 & .01 & -.10 & -.11 \\
\hline Industry-electronics & .09 & .08 & .08 & .04 \\
\hline Firm size (employees) & .00 & -.01 & -.09 & -.08 \\
\hline Evaluation effort & .07 & .08 & $.27 * * *$ & $.30 * * *$ \\
\hline Single supplier & -.03 & -.02 & .10 & .08 \\
\hline Relationship length & -.05 & -.05 & $.21 * *$ & $.23 * * *$ \\
\hline Long-term commitment & $.20 *$ & $.20 *$ & $-.19^{*}$ & $-.22 * *$ \\
\hline Technological newness & -.03 & -.03 & $.29 * * *$ & $.28 * * *$ \\
\hline Supplier responsibility & .00 & -.01 & -.09 & -.10 \\
\hline Item importance & -.02 & -.00 & $.18^{*}$ & $.18^{* *}$ \\
\hline \multicolumn{5}{|l|}{ Main effects: } \\
\hline Supplier technical capabilities & $.40 * * *$ & $.36 * * *$ & .12 & .09 \\
\hline Creative problem-solving task requirement & $.20 * *$ & $.20 * *$ & & \\
\hline Relationship-specific absorptive capacity & & & $.16^{*}$ & $.14^{*}$ \\
\hline Supplier technical performance & & & $.14 *$ & $.15^{*}$ \\
\hline \multicolumn{5}{|l|}{ Interaction effects: } \\
\hline Supplier technical capabilities $\times$ Creative problem-solving task requirement & & $-.11 *$ & & \\
\hline Relationship-specific absorptive capacity $\times$ Supplier technical capabilities & & & & $-.15 * *$ \\
\hline$R^{2}$ & .40 & .42 & .40 & .43 \\
\hline Adjusted $R^{2}$ & .35 & .36 & .34 & .36 \\
\hline$F$ & $7.21 * * *$ & $7.15^{* * *}$ & $6.61 * * *$ & $6.81 * * *$ \\
\hline$n$ & 153 & 153 & 153 & 153 \\
\hline
\end{tabular}

$* p<.05, * * p<.01, * * * p<.001 ; n=153$.

Two-tailed test for control variables; one-tailed for independent variables.

$p<.001)$ (H2a), negatively moderated by supplier problem-solving capability $(\beta=-.11, p<.05)(\mathrm{H} 2 \mathrm{~b})$. H3 was supported with a positive association between relationship-specific absorptive capacity and new product advantage $(\beta=.14, p<.05)$ (H3a), moderated by supplier technical capabilities $(\beta=-.15, p<.01)(\mathrm{H} 3 b)$.

To further understand these interaction effects, we recalculated the regression equations at high and low values for each moderator. We define high and low values as \pm 1 standard deviation from the mean (Cohen and Cohen, 1983). With respect to H2b, Figure 2 shows that high levels of creative problem-solving requirements attenuate (negatively moderate) the relationship between strategic supplier technical capabilities and supplier technical performance, supported by a significant simple slope calculation $(t=6.20, p=.00)$, while low levels of creative problem-solving requirement had a marginal effect $(t=1.79 ; p=.08)$. With respect to H3b, Figure 3 indicates that where a supplier has low levels of technical capabilities, focal firm relationship-specific absorptive capacity has a positive and significant effect on new product advantage. However, where a supplier has high levels of technical capabilities, the effect of relationshipspecific absorptive capacity on new product advantage remains virtually unaffected. This is supported by simple slope computations showing that low levels of supplier technical capabilities was significant $(t=4.71, p=.00)$, while high levels of supplier technical capabilities were nonsignificant $(t=-.09, p=.92)$.

With respect to the control variables, significant associations were found to new product advantage from item importance $(\beta=.18, p<.05)$, technological newness $(\beta=.29, p<.001)$, relationship length $(\beta=.21, p<.01)$, and evaluation effort $(\beta=.27, p<.001)$. Furthermore, long-term relationship commitment was also found to be associated with both supplier technical performance $(\beta=.20, p<.05)$ and new product advantage $(\beta=-.19$, $p<.05)$.

\section{Discussion}

In this study, we investigated how firms configure their resources, and those of their strategic suppliers, to gain a new product advantage, and how different resources can 


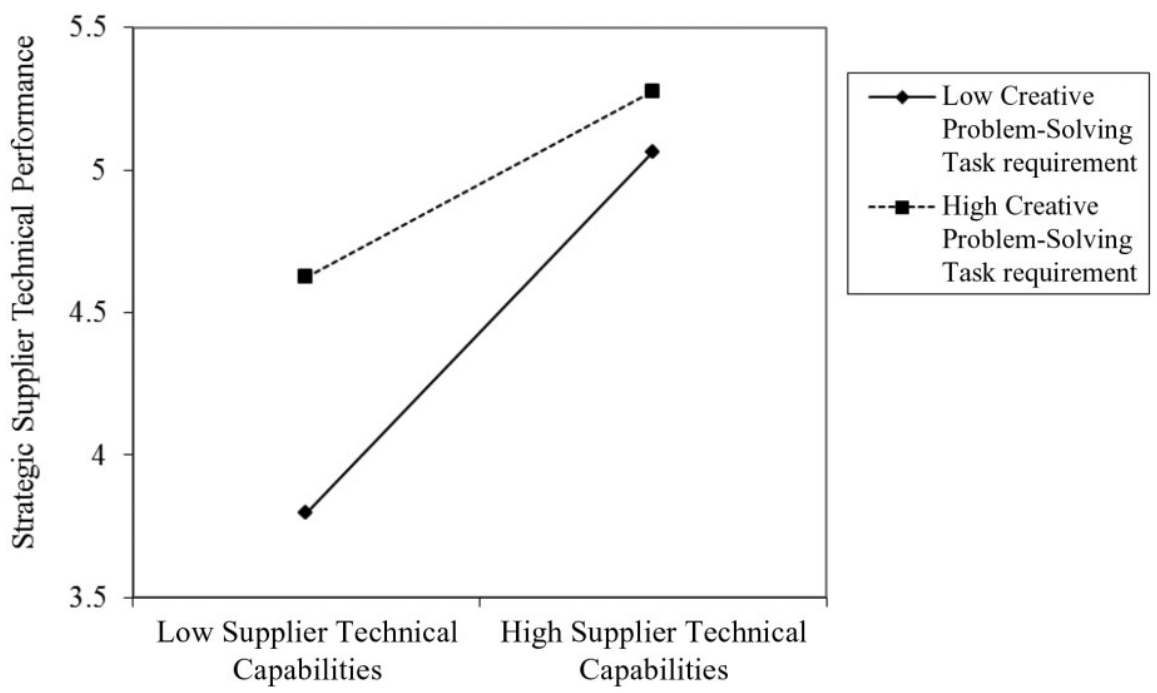

Figure 2. Interaction of Supplier Technical Capabilities and Creative Problem-Solving Task Requirement on Supplier Technical Performance

substitute for one another. While product and process technology define the technical aspects of NPD and the types of specialized knowledge required, the division of tasks between firms and their suppliers remains the domain of buying firms as they mindfully improvise heterogeneous NPD processes (Grant, 1996; Laamanen and Wallin, 2009; Salvato, 2009). Research cautions against drawing universalistic normative implications about firm choices regarding when to internalize or outsource value chain activities (Leiblein, Reuer, and Dalsace, 2002), and recognizes that different configurations of resources are equally effective in contributing to technical innovation (Gruber et al., 2010; Sirmon et al., 2007; Tzabbar et al., 2013). We now discuss each of our results in turn, below.
H1 argued that the extent of new product advantage gained in the market was, at least in part, dependent on the technical performance of the strategic supplier. Our results support this view, showing that supplier technical performance, in terms of their contribution to the competitiveness, functionality, and profitability of the end product, helps to generate a new product advantage. This finding supports the resource and relational perspectives by demonstrating how the joint development of new products, and the integration of suppliers' technical contributions, helps to build a new product's advantage relative to competitors' product offerings (Dyer and Singh, 1998; Lau et al., 2010).

Consistent with expectations, we find support for $\mathrm{H} 2 \mathrm{a}$ that the quality of the technical capabilities possessed by

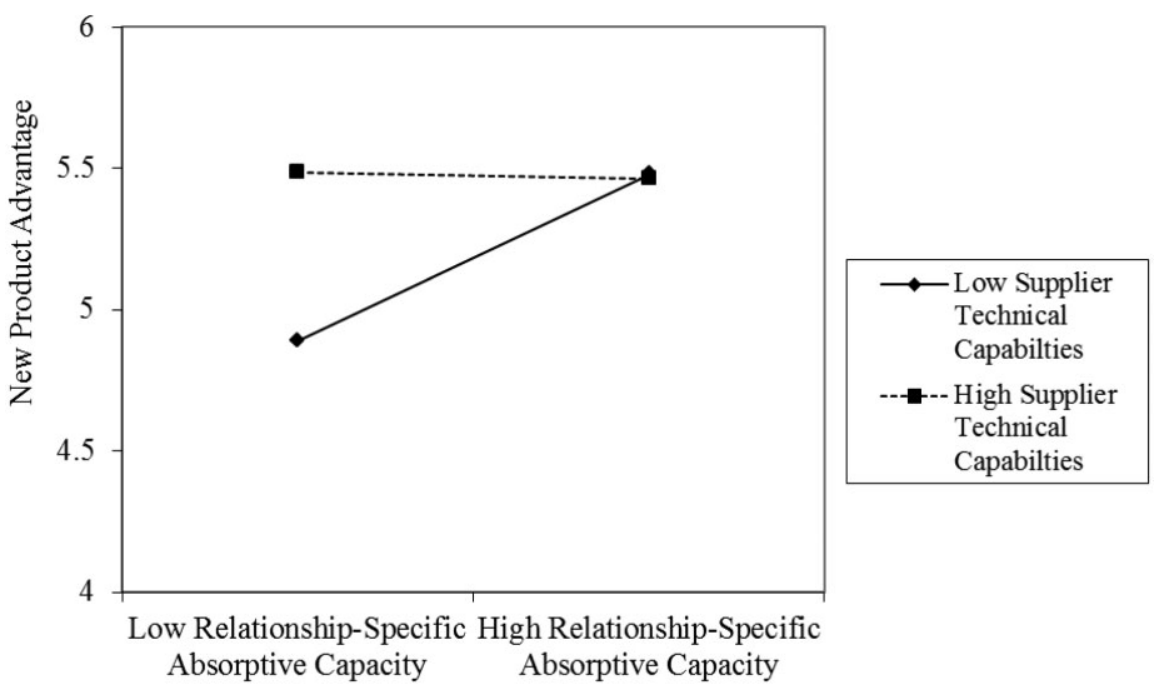

Figure 3. Interaction of Relationship-Specific Absorptive Capacity and Supplier Technical Capabilities on New Product Advantage 
a strategic supplier drives subsequent technical performance. This finding supports the resource-based view, showing that the unique technical capabilities possessed by strategic suppliers, when successfully integrated and exploited within the interorganizational NPD project, can enhance the functionality and competitiveness of the new product when it is launched into the market (Emden et al., 2006).

$\mathrm{H} 2 \mathrm{~b}$ examined whether the extent of a priori creative problem solving required by the supplier task moderated the relationship between supplier technical capabilities and technical performance. The results supported this hypothesis. Under conditions where the supplier's task required only low levels of creative problem solving to be considered a success, increasing levels of supplier technical capabilities led to significantly higher technical performance. In effect, increased technological competence by the supplier could be directly applied to the required product development. By contrast, where the nature of the supplier task required high levels of creative problem solving, the associated increase in uncertainty, complexity, and ambiguity (Fang, 2011; Kogut and Kulatilaka, 2001) makes the existing stock of supplier technical capabilities less effective at contributing to the supplier's technical performance. In such situations, buyers are also less likely to be able to apply their own domain expertise to monitor and instruct the supplier on achieving the project goals (Carson, 2007).

While several studies have examined the effect of absorptive capacity on NPD outcomes (e.g., Tsai, 2009; Vega-Jurado, Gutiérrez-Gracia, Fernández-de-Lucio, and Manjarrés-Henríquez, 2008; Zahra and George, 2002), few have examined relationship-specific absorptive capacity that relates to a single strategic supplier (Ettlie and Pavlou, 2006). Our findings provide strong support for $\mathrm{H} 3 \mathrm{a}$ that investments in developing relationshipspecific absorptive capacity with respect to the strategic supplier lead to improved new product advantage. For strategic suppliers involved in product development activities developing absorptive capacity tailored to the dyad is one of the ways in which interorganizational NPD projects can develop a new product advantage. This finding supports earlier studies by Tanriverdi and Venkatraman (2005) which found that overlapping knowledge and absorptive capacity are necessary factors that facilitate the absorption of technical knowledge from strategic suppliers (Abecassis-Moedas and MahmoudJouini, 2008; Emden et al., 2006).

Finally, our findings provide support for $\mathrm{H} 3 \mathrm{~b}$ that a strategic supplier's technical capabilities would moderate the relationship between relationship-specific absorptive capacity and new product advantage. As shown in Figure 3, in situations where strategic suppliers have low levels of technical capabilities, relationshipspecific absorptive capacity serves a substitution role, enabling the firm to extract relevant ideas, technologies, and innovations from the supplier to facilitate new product advantage. Several explanations for these results are apparent. From a relational view perspective (Dyer and Singh, 1998; Mesquita et al., 2008), the performance gains from such investments in developing relationship-specific capabilities with a strategic supplier are held within the buyer-supplier dyad. Thus, where the supplier has low technical capabilities, incurring higher interaction and coordination costs may be worthwhile in order to extract and absorb the supplier's know-how (Contractor et al., 2011) to generate a new product advantage. It may also be the case that suppliers with low technical capabilities incur internal resource constraints that limit their ability to develop and transfer their technical knowledge across interfirm boundaries (Gibbert et al., 2013). To overcome this problem, firms have to invest in relationship-specific absorptive capacity to successfully identify and absorb the creative know-how developed by their resource-constrained strategic supplier.

By contrast, where suppliers possess strong technical capabilities, investments in relationship-specific absorptive capacity were found to have no significant effect on the level of new product advantage achieved. One explanation is that suppliers possessing advanced technical capabilities are capable of independently fulfilling the requirements of their engagement, with their capabilities subject to a tight appropriability regime (HurmelinnaLaukkanen, Sainio, and Jauhiainen, 2008). Indeed, this is consistent with a resource-based perspective, where the origins of superior performance lie within the supplier's boundaries, and remain inimitable to the firm despite investment in absorptive capacity (Dierickx and Cool, 1989). While the supplier can still deploy their resource across multiple buyers (Mesquita et al., 2008), the supplier's contribution remains a source of competitive parity, or even advantage, as they reflect industry best practices (Weigelt, 2013).

\section{Managerial Implications}

These results offer several key implications for managers. Our findings provide further support for the benefits of involving strategic suppliers in the new product development process. The division of tasks between the firm and its suppliers within this process is a constant managerial 
challenge, and our study sheds light on the different configurations of firms and supplier resources which contribute to a product's advantage in the market. In particular, our study helps managers better direct the allocation of scarce resources within the portfolio of suppliers involved in the new product development project. For example, investing in absorptive capacity unique to the dyad is shown to be worthwhile only where the supplier possesses low technical capabilities, in which situation absorptive capacity can help extract relevant technology from the supplier and deploy it into the firm's end product. By contrast, the appropriability regimes maintained by highly technologically capable suppliers prohibit the transfer of knowledge and technology, with relationship-specific absorptive capacity unlikely to be a source of exclusive advantage for the firm.

Further, improvements in a strategic supplier's technological contribution could be achieved by considering the degree of creativity and problem solving required for them to perform their task successfully. The same design task may present a different level of challenge to different suppliers, so management must tailor their monitoring and interventions to reflect the nature of the task and its match with the supplier's technical capabilities. Where the supplier's task is incremental in nature, and therefore little uncertainty and ambiguity about what is required, the supplier's existing technical capabilities remain useful. Management's span of attention could be preserved by monitoring the supplier's work based on output measures and by exception. In contrast, where the task requires a highly creative solution, then investment in joint problem solving and coordination routines, along with process monitoring of how the supplier is carrying out the task, is more appropriate.

\section{Limitations and Future Directions}

A number of limitations are present in the current study. First, the hypotheses domain and data collection is restricted to industries where the technological environment is dynamic, perceived uncertainty is high, and a resulting high need exists for obtaining and processing new information. Second, we assume that firm and strategic supplier resources are difficult to imitate because they result from unique historical conditions, are socially complex, and the causal linkages between cooperation and performance are ambiguous (Barney, 1991). Crosssectional survey research provides a snapshot of these resources. We encourage further research to conduct longitudinal case studies and explore the evolutionary dynamic processes involved. Finally, consistent with many studies that consider the contributions of suppliers to new product development, our data collection focused on the buyer side of the dyad. Future research should focus on the development of resources from either the supplier's or both partners' perspectives.

Several avenues for future research are also evident. Our study contributes to the literature by highlighting the role of supplier capabilities and firm capabilities in new product advantage. These results should encourage future researchers to explore the microfoundations of supplier technical capabilities and further assess the conditions under which strong supplier technical capabilities serve as complements or substitutes for firm resources. Further, while absorptive capacity is shown to help generate a new product advantage, future research is needed to investigate the role that buyer-supplier collaborative relationships play in aiding this new product advantage. Studies suggest that socialization mechanisms (Lawson, Petersen, Cousins, and Handfield, 2009) and social capital (Carey, Lawson, and Krause, 2011), for example, facilitate interfirm knowledge sharing and improved relational performance. The capabilities of the manufacturing firm itself may also influence these dynamics. Salvador and Villena (2013), for example, show that a firm's capabilities in design modularization can overcome cost and design diseconomies in integration of suppliers into product development. Finally, another fertile area for further research is whether the antecedents and consequences of supplier involvement and new product advantage are more robust under different environmental conditions, such as the level of technological turbulence, degree of uncertainty involved in the supplier's development task, or the newness of the end product.

\section{Conclusions}

This study applied resource-based and relational perspectives to investigate the resource configurations firms use to gain new product advantage, within the context of NPD projects that have extensively involved strategic suppliers. We find that different firm-specific and strategic supplier-specific resource configurations can lead to new product advantage, and indeed, substitute for one another in NPD (Hess and Rothaermel, 2011; Weigelt, 2013). Our findings in particular emphasize the important role that a supplier's technical capabilities and the nature of the supplier task play in building a new product advantage. Further work examining different configurations of firm and supplier-specific resources in interorganizational new product development projects is encouraged. 


\section{References}

Abecassis-Moedas, C., and B. Mahmoud-Jouini. 2008. Design, absorptive capacity, source-recipient knowledge complementarity and new product development performance: An empirically derived framework. Journal of Product Innovation Management 25 (6): 473-90.

Anderson, J. C., and D. W. Gerbing. 1988. Structural equation modeling in practice: A review and recommended two-step approach. Psychological Bulletin 103: 411-23.

Andrews, J., and D. C. Smith. 1996. In search of the marketing imagination: Factors affecting the creativity of marketing programs for mature products. Journal of Marketing Research 33 (2): 174-87.

Armstrong, S. J., and T. S. Overton. 1977. Estimating non-response bias in mail surveys. Journal of Marketing Research 14 (3): 396-402.

Arora, A., and M. Ceccagnoli. 2006. Patent protection, complementary assets, and firms' incentives for technology licensing. Management Science 52 (2): 293-308.

Atuahene-Gima, K., and Y. Wei. 2011. The vital role of problem-solving competence new product success. Journal of Product Innovation Management 28 (1): 81-98.

Azadegan, A., and K. J. Dooley. 2010. Supplier innovativeness, organizational learning styles and manufacturer performance: An empirical assessment. Journal of Operations Management 28 (6): 488-505.

Bagozzi, R. P., and Y. Yi. 1988. On the evaluation of structural models. Journal of the Academy of Marketing Science 16 (1): 74-94.

Barney, J. 1991. Firm resources and sustained competitive advantage. Journal of Management 17 (1): 99-120.

Brusoni, S., A. Prencipe, and K. Pavitt. 2001. Knowledge specialisation, organizational coupling and the boundaries of the firm: Why firms know more than they make? Administrative Science Quarterly 46 (4): 597-621.

Bstieler, L., and M. Hemmert. 2010. Increasing learning and time efficiency in interorganizational new product development teams. Journal of Product Innovation Management 27 (4): 485-99.

Carey, S., B. Lawson, and D. R. Krause. 2011. Social capital configuration, legal bonds and performance in buyer-supplier relationships. Journal of Operations Management 29 (4): 277-88.

Carson, S. J. 2007. When to give up control of outsourced new product development. Journal of Marketing 71 (1): 49-66.

Cassiman, B., and R. Veugelers. 2006. In search of complementarity in innovation strategy: Internal R\&D and external knowledge acquisition. Management Science 52 (1): 68-82.

Cheung, M.-S., M. B. Myers, and J. T. Mentzer. 2011. The value of relational learning in global buyer-supplier exchanges: A dyadic perspective and test of the pie-sharing premise. Strategic Management Journal 32 (4): 1061-82.

Clark, K. B. 1989. Project scope and project performance: The effect of parts strategy and supplier involvement on product development. Management Science 35 (10): 1247-63.

Clark, K. B., and T. Fujimoto. 1991. Product development performance. Boston, MA: Harvard Business School Press.

Cohen, J., and P. Cohen. 1983. Applied multiple regression/correlation analyses for the behavioral sciences. Hillsdale, NJ: Lawrence Erlbaum Associates.

Collis, D. J. 1994. How valuable are organizational capabilities? Strategic Management Journal 15: 143-52.

Contractor, F. J., J. A. Woodley, and A. Piepenbrink. 2011. How tight an embrace? Choosing the optimal degree of partner interaction in alliances based on risk, technology characteristics, and agreement provisions. Global Strategy Journal 1 (1-2): 67-85.

Cooper, A. C., and A. V. Bruno. 1977. Success among high-technology firms. Business Horizons 20 (2): 16-22.

Davis, J. P., and K. M. Eisenhardt. 2011. Rotating leadership and collaborative innovation: Recombination processes in symbiotic relationships. Administrative Science Quarterly 56 (2): 159-201.
Davis, J. P., K. M. Eisenhardt, and C. B. Bingham. 2009. Optimal structure, market dynamism, and the strategy of simple rules. Administrative Science Quarterly 54 (3): 413-52.

Dierickx, I., and K. Cool. 1989. Asset stock accumulation and the sustainability of competitive advantage. Management Science 35 (12): 1504-11.

Dillman, D. A. 2000. Mail and internet surveys: The tailored design method. New York: John Wiley \& Sons.

Droge, C., R. Calantone, and N. Harmancioglu. 2008. New product success: Is it really controllable by managers in highly turbulent environments? Journal of Product Innovation Management 25 (3): 272-86.

Dyer, J. H. 1996. Specialized supplier networks as a source of competitive advantage: Evidence from the auto industry. Strategic Management Journal 17 (4): 271-91.

Dyer, J. H., and N. W. Hatch. 2006. Relation-specific capabilities and barriers to knowledge transfers: Creating advantage through network relationships. Strategic Management Journal 27: 701-19.

Dyer, J. H., and K. Nobeoka. 2000. Creating and managing a highperformance knowledge-sharing network: The Toyota case. Strategic Management Journal 21 (3): 345-67.

Dyer, J. H., and H. Singh. 1998. The relational view: Cooperative strategy and sources of interorganizational competitive advantage. Academy of Management Review 23 (4): 660-79.

Dyer, J. H., D. S. Cho, and W. Chu. 1998. Strategic supplier segmentation: The next "best practice" in supply chain management. California Management Review 40 (2): 57-77.

Dyer, J. H., P. Kale, and H. Singh. 2001. How to make strategic alliances work. Sloan Management Review 42 (4): 37-43.

Eisenhardt, K. M., and Martin, J.A. 2000. Dynamic capabilities: What are they? Strategic Management Journal 21 (10/11): 1105-21.

Emden, Z., R. Calantone, and C. Droge. 2006. Collaborating for new product development: Selecting the partner with maximum potential to create value. Journal of Product Innovation Management 23 (4): 330 41

Ettlie, J. E., and P. A. Pavlou. 2006. Technology-based new product development partnerships. Decision Sciences 37 (2): 117-47.

Fang, E. 2011. The effect of strategic alliance knowledge complementarity on new product innovativeness in China. Organization Science 22 (1): $158-72$.

Fornell, C., and D. F. Larcker. 1981. Evaluating structural equation models with unobservable variables and measurement error. Journal of Marketing Research 18 (1): 39-50.

Gerbing, D. W., and J. C. Anderson. 1992. Monte Carlo evaluations of goodness of fit indices for structural equation models. Sociological Methods and Research 21 (2): 132-60.

Gibbert, M., M. Hoegl, and L. Valikangas. 2013. Introduction to the special issue: Financial resource constraints and innovation. Journal of Product Innovation Management 31 (2): 197-201.

Grant, R. M. 1996. Prospering in dynamically-competitive environments: Organizational capability as knowledge integration. Organization Science 7 (4): 375-87.

Greene, W. H. 2002. Econometric analysis. Upper Saddle River, NJ: Prentice Hall.

Gruber, M., F. Heinemann, M. Brettel, and S. Hungeling. 2010. Configurations of resources and capabilities and their performance implications: An exploratory study on technology ventures. Strategic Management Journal 31 (12): 1337-56.

Gulati, R. 1995. Social structure and alliance formation pattern: A longitudinal analysis. Administrative Science Quarterly 40: 619-42.

Hair, J. F., W. C. Black, B. Babin, R. E. Anderson, and R. L. Tatham. 2006. Multivariate data analysis. Upper Saddle River, NJ: Prentice-Hall.

Handfield, R. B. 2006. Supply market intelligence: A handbook for managers. Boca Raton, FL: Auerbach Publications. 
Handfield, R. B., G. L. Ragatz, K. J. Petersen, and R. M. Monczka. 1999. Involving suppliers in new product development. California Management Review 42 (1): 59-82.

Hartley, J. L., B. J. Zirger, and R. R. Kamath. 1997. Managing the buyersupplier interface for on-time performance in product development Journal of Operations Management 15: 57-70.

Håkansson, H. 1982. An interaction approach. In International marketing and purchasing of industrial goods: An interaction approach. ed. $\mathrm{H}$. Håkansson, 10-27. Chichester, UK: John Wiley \& Sons.

Helfat, C. E., and M. Peteraf. 2003. The dynamic resource-based view: Capability lifecycles. Strategic Management Journal 24 (10): 997 1010.

Hess, A. M., and F. T. Rothaermel. 2011. When are assets complementary? Star scientists, strategic alliances, and innovation in the pharmaceutical industry. Strategic Management Journal 32 (8): 895-909.

Hua, S., and U. Wemmerlöv. 2006. Product change intensity, product advantage, and market performance: An empirical investigation of the PC industry. Journal of Product Innovation Management 23: 316-29.

Hurmelinna-Laukkanen, P., L.-M. Sainio, and T. Jauhiainen. 2008 Appropriability regime for radical and incremental innovations. $R \& D$ Management 38 (3): 278-89.

Jacobides, M. G., and S. G. Winter. 2005. The co-evolution of capabilities and transaction costs: Explaining the institutional structure of production. Strategic Management Journal 26 (5): 395-413.

Kim, N., and K. Atuahene-Gima. 2010. Using exploratory and exploitative market learning for new product development. Journal of Product Innovation Management 27 (4): 519-36.

Kogut, B., and N. Kulatilaka. 2001. Capabilities as real options. Organization Science 12 (6): 744-58.

Kraatz, M. S., and E. J. Zajac. 2001. How resources affect strategic change and performance in turbulent environments. Organization Science 12: 632-57.

Kumar, N., L. W. Stern, and J. C. Anderson. 1993. Conducting interorganizational research using key informants. Academy of Management Journal 36 (6): 1633-51.

Laamanen, T., and J. Wallin. 2009. Cognitive dynamics of capability development paths. Journal of Management Studies 46 (6): 950-81.

LaBahn, D., and R. Krapfel. 2000. Early supplier involvement in customer new product development: A contingency model of component supplier intentions. Journal of Business Research 47 (3): 173-91.

Langerak, F., and E. J. Hultink. 2005. The impact of new product development acceleration approaches on speed and profitability: Lessons for pioneers and fast followers. IEEE Transactions on Engineering Management 52 (1): 30-42.

Lau, A. K. W., E. Tang, and R. C. M. Yam. 2010. Effects of supplier and customer integration on product innovation and performance: Empirical evidence in Hong Kong manufacturers. Journal of Product Innovation Management 27 (5): 761-77.

Lau, A. K. W., R. C. M. Yam, and E. Tang. 2011. The impact of product modularity on new product performance: Mediation by product innovativeness. Journal of Product Innovation Management 28 (2): 270-84.

Lawson, B., D. Krause, and A. Potter. In Press. Improving supplier new product development performance: the role of supplier development. Journal of Product Innovation Management. DOI: 10.1111/jpim.12231

Lawson, B., and A. Potter. 2012. Determinants of knowledge transfer in inter-firm new product development projects. International Journal of Operations \& Production Management 32 (10): 1228-47.

Lawson, B., K. J. Petersen, P. D. Cousins, and R. B. Handfield. 2009. Knowledge sharing in interorganizational product development teams: The effect of formal and informal socialization mechanisms. Journal of Product Innovation Management 26 (2): 156-72.

Leiblein, M. J., J. J. Reuer, and F. Dalsace. 2002. Do make or buy decisions matter? The influence of organizational governance on technological performance. Strategic Management Journal 23 (9): 817-33.
Liker, J. K., R. R. Kamath, S. N. Wasti, and M. Nagamachi. 1996. Supplier involvement in automotive component design: Are there really large US Japan differences? Research Policy 25: 59-89.

McNally, R. C., E. Cavusgil, and R. J. Calantone. 2010. Product innovativeness dimensions and their relationships with product advantage, product financial performance, and project protocol. Journal of Product Innovation Management 27: 991-1006.

Mesquita, L. F., J. Anand, and T. H. Brush. 2008. Comparing the resourcebased and relational views: Knowledge transfer and spillover in vertical alliances. Strategic Management Journal 29 (9): 913-41.

Monczka, R. M., K. J. Petersen, R. B. Handfield, and G. L. Ragatz. 1998. Success factors in strategic supplier alliances: The buying company perspective. Decision Sciences 29 (3): 553-77.

Nelson, R., and S. Winter. 1982. An evolutionary theory of economic change. Cambridge, MA: Harvard University Press.

Paulraj, A., A. A. Lado, and I. J. Chen. 2008. Inter-organizational communication as a relational competency: Antecedents and performance outcomes in collaborative buyer-supplier relationships. Journal of Operations Management 26: 45-64.

Pavlou, P. A., and O. A. El Sawy. 2006. From IT leveraging competence to competitive advantage in turbulent environments: The case of new product development. Information Systems Research 17 (3): 198227.

Petersen, K. J., R. B. Handfield, and G. L. Ragatz. 2003. A model of supplier integration into new product development. Journal of Product Innovation Management 20 (4): 284-99.

Petersen, K. J., R. B. Handfield, and G. L. Ragatz. 2005. Supplier integration into new product development: Coordinating product, process and supply chain design. Journal of Operations Management 23 (4): 371 88.

Potter, A., and B. Lawson. 2013. Help or hindrance? Causal ambiguity and supplier involvement in new product development teams. Journal of Product Innovation Management, 30 (4): 794-808.

Ragatz, G. L., R. B. Handfield, and T. V. Scannell. 1997. Success factors for integrating suppliers into new product development. Journal of Product Innovation Management 14 (3): 190-202.

Rauniar, R., W. J. Doll, G. E. Rawskic, and P. Hong. 2008. Shared knowledge and product design glitches in integrated product development. International Journal of Production Economics 114 (2): 723-36.

Reed, R., and R. J. DeFillippi. 1990. Causal ambiguity, barriers to imitation, and sustainable competitive advantage. Academy of Management Review 15 (1): 88-102.

Richardson, J., and J. Roumasset. 1995. Sole sourcing, competitive sourcing, parallel sourcing: Mechanism for supplier performance. Managerial and Decision Economics 16 (1): 71-84.

Rijsdijk, S. A., F. Langerak, and E. J. Hultink. 2011. Understanding a two-sided coin: Antecedents and consequences of a decomposed product advantage. Journal of Product Innovation Management 28 (1): 33-47.

Salvador, F., and V. H. Villena. 2013. Supplier integration and NPD outcomes: Conditional moderation effects of modular design competence. Journal of Supply Chain Management 49 (1): 87-113.

Salvato, C. 2009. Capabilities unveiled: The role of ordinary activities in the evolution of product development processes. Organization Science 20 (2): 384-409.

Santos, F. M., and K. M. Eisenhardt. 2005. Organizational boundaries and theories of organization. Organization Science 16 (5): 491-508.

Simonin, B. L. 1999. Ambiguity and the process of knowledge transfer in strategic alliances. Strategic Management Journal 20 (7): 595-623.

Sirmon, D. G., M. A. Hitt, and R. D. Ireland. 2007. Managing firm resources in dynamic environments to create value: Looking inside the black box. Academy of Management Review 32 (1): 273-92.

Song, L. Z., M. Song, and C. A. Di Benedetto. 2011. Resources, supplier investment, product launch advantages, and first product performance. Journal of Operations Management 29 (1-2): 86-104. 
Song, M., and C. A. Di Benedetto. 2008. Supplier's involvement and success of radical new product development in new ventures. Journal of Operations Management 26 (1): 1-22.

Song, M., and M. M. Montoya-Weiss. 2001. The effect of perceived technological uncertainty on Japanese new product development. Academy of Management Journal 44 (1): 61-80.

Song, M., and M. E. Parry. 1997. The determinants of Japanese new product successes. Journal of Marketing Research 34 (1): 64-76.

Song, X. M., and M. E. Parry. 1996. What separates Japanese new product winners from losers. Journal of Product Innovation Management 13: 422-39.

Song, X. M., W. E. Souder, and B. Dyer. 1997. A causal model of the impact of skills, synergy, and design sensitivity on new product performance. Journal of Product Innovation Management 14 (2): 88-101.

Takeishi, A. 2001. Bridging inter- and intra-firm boundaries: Management of supplier involvement in automobile product development. Strategic Management Journal 22: 403-33.

Tanriverdi, H., and N. Venkatraman. 2005. Knowledge relatedness and the performance of multibusiness firms. Strategic Management Journal 26 (2): 97-119.

Teece, D. J., G. Pisano, and A. Shuen. 1997. Dynamic capabilities and strategic management. Strategic Management Journal 18 (7): 509-33.

Tsai, K.-H. 2009. Collaborative networks and product innovation performance: Toward a contingency perspective. Research Policy 38 (5): 765-78.

Tzabbar, D., B. S. Aharonson, and T. L. Amburgey. 2013. When does tapping external sources of knowledge result in knowledge integration? Research Policy 42 (2): 481-94. van Echtelt, F. E. A., F. Wynstra, and A. J. van Weele. 2007. Strategic and operational management of supplier involvement in new product development: A contingency perspective. IEEE Transactions on Engineering Management 54 (4): 644-61.

von Hippel, E. 1994. Sticky information and the locus of problem solving: Implications for innovation. Management Science 40: 429-39.

Vega-Jurado, J., A. Gutiérrez-Gracia, I. Fernández-de-Lucio, and L. Manjarrés-Henríquez. 2008. The effect of external and internal factors on firms' product innovation. Research Policy 37 (4): 616-32.

Volberda, H. W., and A. Y. Lewin. 2003. Co-evolutionary dynamics within and between firms: From evolution to co-evolution. Journal of Management Studies 40 (8): 2111-36.

Wagner, S. M. 2012. Tapping supplier innovation. Journal of Supply Chain Management 48 (2): 37-52.

Wasti, N. S., and J. K. Liker. 1997. Risky business or competitive power? Supplier involvement in Japanese product design. Journal of Product Innovation Management 14 (5): 337-55.

Weigelt, C. 2013. Leveraging supplier capabilities: The role of locus of capability deployment. Strategic Management Journal 34 (1): 1-21.

Wernerfelt, B. 1984. A resource based view of the firm. Strategic Management Journal 5 (5): 171-80.

Womack, J. P., D. Jones, and D. T. Roos. 1990. The machine that changed the world. New York: Rawlinson Associates.

Wynstra, F., F. von Corswant, and M. Wetzels. 2010. In chains? An empirical study of antecedents of supplier product development activity in the automotive industry. Journal of Product Innovation Management 27 (5): 625-39.

Zahra, S. A., and G. George. 2002. Absorptive capacity: A review, reconceptualization, and extension. Academy of Management Review 27 (2): 185-203. 